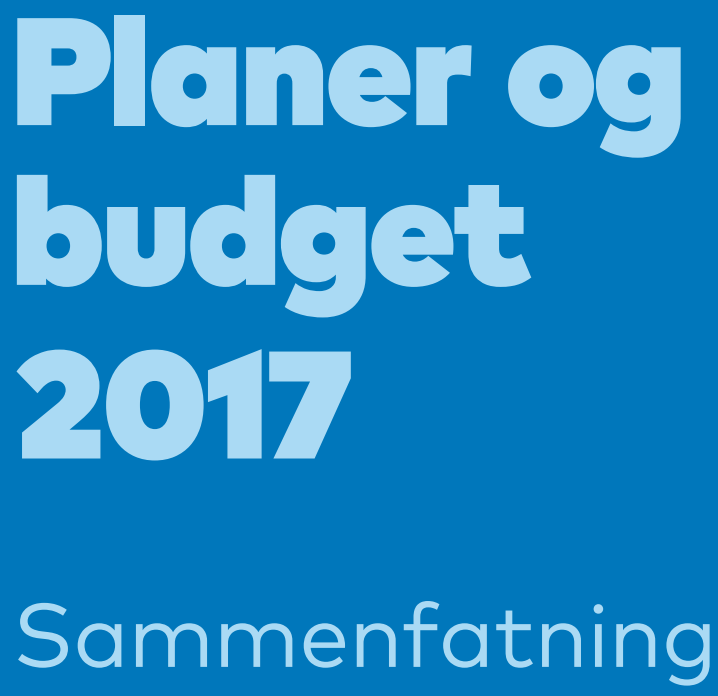

III) Nordisk

Ministerråd 


\section{Planer og budget 2017 - sammenfatning}

ISBN 978-92-893-4857-7 (PRINT)

ISBN 978-92-893-4858-4 (PDF)

http://dx.doi.org/10.6027/ANP2017-706

ANP 2017:706

(c) Nordisk Ministerråd 2017

Layout: Erling Lynder

Tryk: Rosendahls

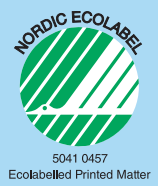

Printed in Denmark

www.norden.org/nordpub

\section{Det nordiske samarbejde}

Det nordiske samarbejde er en af verdens mest omfattende regionale samarbejdsformer. Samarbejdet omfatter Danmark, Finland, Island, Norge og Sverige samt Færøerne, Grønland og Åland.

Det nordiske samarbejde er både politisk, økonomisk og kulturelt forankret og er en vigtig medspiller i det europæiske og internationale samarbejde. Det nordiske fællesskab arbejder for et stærkt Norden i et stærkt Europa.

Det nordiske samarbejde ønsker at styrke nordiske og regionale interesser og værdier i en global omverden. Fælles værdier landene imellem er med til at styrke Nordens position som en af verdens mest innovative og konkurrencedygtige regioner.

\section{Nordisk Ministerråd}

Ved Stranden 18 1061 København K www.norden.org 


\section{Planer og budget 2017 - sammenfatning}

\section{Indholdsfortegnelse}

Planer og budget 2017

Budgettets totalramme og budgettet fordelt på budgetsektorer

Hovedlinjer i budget 2017

Ministerrådenes politiske prioriteringer

Drøftelser med Nordisk Råd om Nordisk Ministerråds budget 2017

Budgettets indtægter og landenes indbetalinger

Landenes prognosticerede indbetalinger i national valuta

Udviklingen i Nordisk Ministerråds budget

Budgettets udvikling i perioden 2005-2017

Besparelse i det nordiske budget 2014-2016

Udviklingen i udisponerede midler 2012-2015

Likviditetens udvikling

Oversigt over Nordisk Ministerråds budget på budgetpostniveau

Bilag 1: De nordiske institutioners bevillinger i national valuta

Bilag 2: Valutakurser og inflationssatser 2017 


\section{Planer og budget 2017}

Det nordiske samarbeidet har siden 2014 vært preget av et omfattende reformarbeid under overskriften "Nytt Norden". I 2016 besluttet de nordiske samarbeidsministre å gå inn i neste fase av reformarbeidet. Målet er å sikre samarbeidets relevans for landene, næringslivet og sivilsamfunnet.

Det nordiske budsjettet spiller en sentral rolle som et verktøy for styring og prioritering for det nordiske samarbeidet. Store samfunnsmessige utfordringer har også betydning for det nordiske samarbeidet. Det gjelder hvordan vi eksempelvis møter konsekvenser av geopolitiske endringer, migrasjon og klimautfordringer. Økt internasjonal oppmerksomhet omkring nordiske løsninger representerer nye muligheter. Dette krever et dynamisk og fleksibelt samarbeid hvor budsjettet er et viktig redskap for å realisere nye løsninger på nye utfordringene.

Prioriteringene i budsjettet for 2017 reflekterer et ønske om at det nordiske samarbeidet skal svare på de viktigste felles utfordringene i de nordiske landene. En bred tverrgående satsning på samarbeidet om integrering av flyktninger og innvandrere er således ett av hovedelementene i forslaget. Samarbeidet på dette området tar sikte på å bygge og utveksle kunnskap om beste praksis innenfor integreringsfeltet. Det etableres en felles nordisk clearingsentral for nettverksbygging og kunnskapsutveksling, oppbygning av forskningskunnskap samt fokus på hvordan sivilsamfunnet kan bidra til integrering.

For å møte den økende interessen for Norden utenfor regionen er det fra 2016 iverksatt en felles nordisk strategi for profilering og posisjonering av Norden. Denne satsingen videreføres i 2017. Basert på de gode erfaringer fra Nordic Cool-satsningen i Washington DC i 2013, legges det i 2017 opp til en bred markering i samarbeid med kultursenteret Southbank i London.

I 2017 iverksettes et nytt initiativ fra de nordiske statsministre om felles 
nordiske løsninger om globale utfordringer. Disse vil imøtekomme internasjonal etterspørsel etter innovative samfunnsløsninger på områder hvor de nordiske land har spisskompetanse.

Som ledd i reformarbeidet er det igangsatt strategiske gjennomlysninger for å identifisere potensialet i nordisk samarbeid på utvalgte områder i et 5-10-årsperspektiv. I budsjettforslaget er det satt av midler til videre oppfølging av forslagene i Könberg-rapporten på helseområdet. Videre er det satt av midler til oppfølging av den strategiske gjennomlysningen på arbeidsmarkedsområdet (Nielsonrapporten) og til gjennomlysningen av energisamarbeidet som avsluttes i mars 2017. Arbeidet ledes av Jorma Ollila. Denne arbeidsformen har vist seg vellykket og vil derfor bli videreført på miljøområdet i 2017.
Det har vært en god og konstruktiv dialog gjennom hele budsjettprosessen med Nordisk råd. I den årlige drøftelse med Nordisk råd våren 2016 om Nordisk ministerråds budsjett ble det oppnådd enighet om et kompromiss. Dette budsjettkompromisset er i sin helhet tatt inn i budsjettboken.

Den totale ramme for budsjettet er på nivå med 2016. Ordningen med et prioriteringsbudsjett som også inneholder formannskapslandets prosjekter, videreføres i 2017 under norsk formannskap.

København 10. november 2016

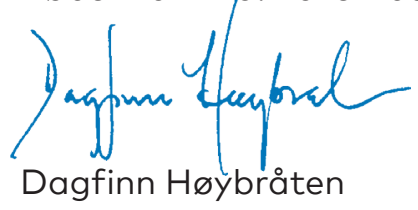

Generalsekretær

i Nordisk ministerråd 


\section{Budgettets totalramme og budgettet fordelt på budgetsektorer}

Den totale udgiftsramme for 2017 for Nordisk Ministerråd er i alt 935.091 TDKK, som er uændret realramme i forhold til budget 2016 .

Rammen kan specificeres således:

\begin{tabular}{lr}
$\begin{array}{l}\text { Sammensætningen af } \\
\text { den samlede ramme }\end{array}$ & TDKK \\
\hline $\begin{array}{l}\text { Vedtaget budget } 2017 \text { i } \\
\text { 2016-priser }\end{array}$ & 927.546 \\
$\begin{array}{l}\text { Prisomregningseffekt til } \\
\text { 2017-prisniveau } \\
\text { Valutaomregningseffekt }\end{array}$ & -9.756 \\
\hline Total i 2017-priser & $\mathbf{9 3 5 . 0 9 1}$ \\
\hline
\end{tabular}

Til budgetrammen for 2017

(i 2016-priser) lægges effekten af pris- og valutaomregningen med de prisomregningsfaktorer og valutakurser, som vises i bilag 2, og det giver den totale udgiftsramme for Nordisk Ministerråd for 2017.

Effekten af prisomregningen i budget 2017 indebærer en inflationskompensation på 17.301 TDKK, svarende til en gennemsnitlig prisomregningsprocent på 1,9\%. Effekten af valutaomregningen til DKK af institutionernes bevillinger i national valuta indebærer en reduktion i budgettet på 9.756 TDKK. Det skal dog understreges, at det ikke har nogen realvirkning på budgettets størrelse (og landenes indbetalinger) eller på størrelsen af institutionernes bevillinger. Valutakurserne benyttes alene til at omregne institutioners bevillinger, som udbetales i domicillandets valuta, til DKK.

På næste side ses fordelingen af udgiftsrammen på budgetsektorer for 2017. 


\section{Sammenstilling af budget 2017 og 2016 (løbende priser)}

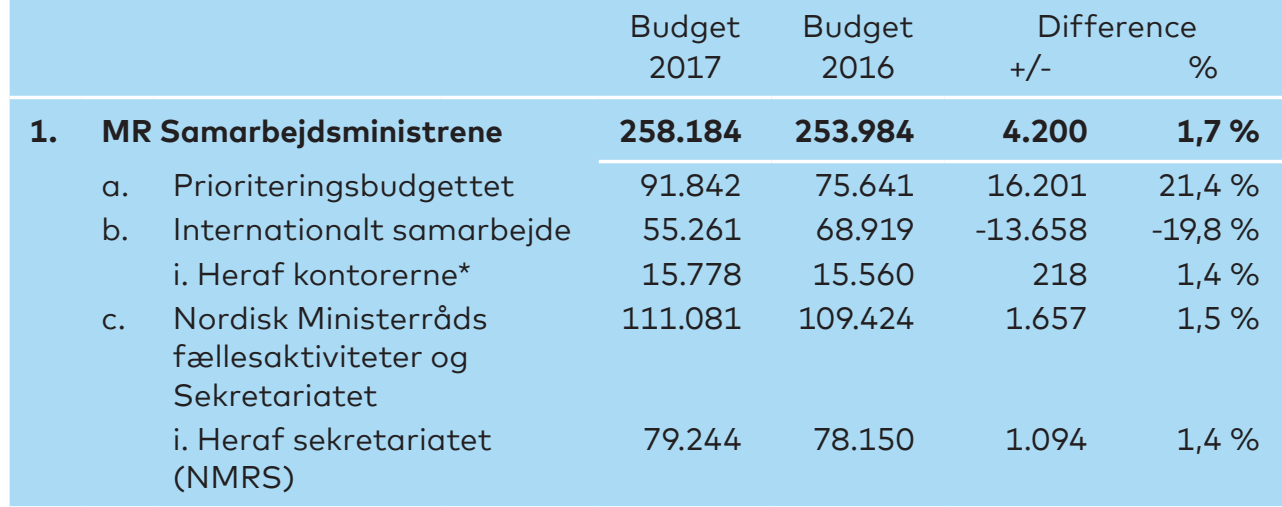

2. MR Uddannelse og forskning
a. Generelle forsknings-og uddannelsesinitiativer
b. Politikudvikling m.v.
c. Mobilitets-og netværks- programmer
d. NordForsk (institution)
e. Forskning i øvrigt

\begin{tabular}{rrrr|}
\hline 221.541 & 222.919 & -1.378 & $-0,6 \%$ \\
\hline 3.376 & 3.316 & 60 & $1,8 \%$ \\
15.718 & 15.440 & 278 & $1,8 \%$ \\
80.306 & 77.713 & 2.593 & $3,3 \%$ \\
99.442 & 104.153 & -4.711 & $-4,5 \%$ \\
22.699 & 22.297 & 402 & $1,8 \%$ \\
\hline 39.363 & 38.732 & 631 & $1,6 \%$ \\
\hline 20.083 & 19.794 & 289 & $1,5 \%$ \\
\hline
\end{tabular}

\section{MR Social- og Helsepolitik}

i. Heraf Nordens Välfärdscenter (institution)

4. MR Kulturpolitik

$\mathbf{1 7 4 . 4 1 3}$

$$
170.551
$$

3.862

$2,3 \%$

a. Generelle kultursatsninger

51.496

51.085

6.250

6.139

411

$0,8 \%$

b. Børn og Unge

31.846

31.283

111

$1,8 \%$

c. Film og Media

31.820

31.258

563

$1,8 \%$

d. Kunstområdet

46.010

44.219

562

$1,8 \%$

e. Nordiske Kulturhuse (institutioner)

f. Andre kultursatsninger

6.991

6.567

1.791

$4,1 \%$

5. MR Fiskeri og havbrug, Jordbrug, Levnedsmidler og Skovbrug
a. Fiskeri
b. Jord-og Skovbrug
i. Heraf NordGen (institution)
c. Levnedsmidler

$\begin{array}{rrrr}6.416 & 6.303 & 113 & 1,8 \% \\ 27.074 & 26.659 & 415 & 1,6 \% \\ 19.769 & 19.484 & 285 & 1,5 \% \\ 6.729 & 6.610 & 119 & 1,8 \%\end{array}$


Sammenstilling af budget 2017 og 2016 (løbende priser)

\begin{tabular}{|c|c|c|c|c|c|}
\hline & \multirow{2}{*}{$\begin{array}{c}\text { Budget } \\
2017\end{array}$} & \multirow{2}{*}{$\begin{array}{c}\text { Budget } \\
2016\end{array}$} & \multicolumn{2}{|c|}{ Difference } \\
\hline & & & & $+/-$ & $\%$ \\
\hline 6. & MR Ligestilling & 9.185 & 9.023 & 162 & $1,8 \%$ \\
\hline \multirow[t]{7}{*}{7.} & $\begin{array}{l}\text { MR Närings-, Energi- og } \\
\text { Regionalpolitik }\end{array}$ & 129.080 & 130.773 & -1.693 & $-1,3 \%$ \\
\hline & a. Näring & 85.664 & 87.766 & -2.102 & $-2,4 \%$ \\
\hline & $\begin{array}{l}\text { i. Heraf Nordisk Innovation } \\
\text { (institution) }\end{array}$ & 67.910 & 70.326 & -2.416 & $-3,4 \%$ \\
\hline & b. Energi & 10.322 & 10.461 & -139 & $-1,3 \%$ \\
\hline & $\begin{array}{l}\text { i. Heraf Nordisk Energi- } \\
\text { forskning (institution) }\end{array}$ & 6.046 & 6.261 & -215 & $-3,4 \%$ \\
\hline & c. Regional & 33.094 & 32.546 & 548 & $1,7 \%$ \\
\hline & $\begin{array}{l}\text { i. Heraf Nordregio } \\
\text { (institution) }\end{array}$ & 11.114 & 10.954 & 160 & $1,5 \%$ \\
\hline 8. & MR Miljø & 45.716 & 44.907 & 809 & $1,8 \%$ \\
\hline \multirow[t]{2}{*}{9.} & MR Arbejdsmarkedspolitik & 14.086 & 13.839 & 247 & $1,8 \%$ \\
\hline & i. Heraf NIVA (institution) & 3.461 & 3.403 & 58 & $1,7 \%$ \\
\hline 10. & MR Ekonomi og Finanspolitik & 1.874 & 1.841 & 33 & $1,8 \%$ \\
\hline 11. & MR Lagstiftning & 1.430 & 1.405 & 25 & $1,8 \%$ \\
\hline & Totalt nordisk budget & 935.091 & 927.546 & 7.545 & $0,8 \%$ \\
\hline
\end{tabular}

*Ministerrådets kontorer i Estland, Letland, Litauen og Nordvestrusland

Rammerne i DKK fordelt på budgetpostniveau ses i tabel på side 24. 


\section{Hovedlinjer i budget 2017}

Nordiska ministerrådet är ett forum för det formella samarbetet mellan de nordiska regeringarna. Ministerrådets arbete regleras av Helsingforsavtalet som senast ändrades 1995.

Ordförandeskapet för Nordiska ministerrådet roterar mellan länderna på årlig basis. Norge tar 2017 över ordförandeskapsrollen efter Finland.

Det är de nordiska samarbetsministrarna (MR-SAM), som har det övergripande ansvaret för att koordinera arbetet i Nordiska ministerrådet. Därtill utförs samarbetet $\mathrm{i}$ tio fackministerråd.

Den nordiska budgeten har i perioden 2014-2016 reducerats med sammanlagt $8 \%$ i fasta priser. I år är dock den totala ramen för den nordiska budgeten oförändrad i förhållande till 2016. Fördelningen mellan sektorerna följer fördelningen från 2016.

Inför 2017 har emellertid samarbetsministrarna omprioriterat inom ramen för sin budget. Konsekvensen är att prioriteringsbudgeten utökats. Syftet är att möjliggöra nya omfattande politiska satsningar. För mer information se avsnittet om huvudlinjer i Nordiska ministerrådet för politiska prioriteringar.

Vidare fortsätter ordförandeskapsprojekten från Danmark (2015) och Finland (2016) under 2017. Dessutom lanserar Norge sina prioriterade ordförandeskapsprojekt.

Budgeten har utarbetats mot bakgrund av fackministerrådens bidrag till prioriteringar och presenterades som generalsekreterarens budgetförslag juni 2016. Förslaget skickas därefter på nationell remiss i de nordiska länderna. Samarbetsministrarna fattades i september 2016 beslut som budgetförslaget. Den slutgiltiga budgeten för Nordiska ministerrådet 2017 antogs av de nordiska samarbetsministrarna i november 2016 efter diskussioner med Nordiska rådet. 


\section{Ministerrådenes politiske prioriteringer}

Generalsekreteraren fick 2013 uppdraget att se på möjligheterna för att effektivisera och förbättra det nordiska regeringssamarbetet. Mot bakgrund av rapporten Nytt Norden beslutade samarbetsministrarna i juni 2014 om rapportens konklusioner, som har implementerats 2014-16.

Reform fortsätter att vara ett centralt tema för det nordiska samarbetet i år. Anledningen är den uppföljande Nytt Norden 2.0-rapport som initierades i februari 2016.

Ett verktyg som kan bidra till ökad relevans i det nordiska regeringssamarbetet är de nordiska samarbetsministrarnas prioriteringsbudget. Denna budget, vars syfte är att möjliggöra och facilitera igångsättandet av nya och större tvärgående projekt/program samt ländernas ordförandeskapssatsningar, har existerat sedan 2013.

I 2017 används prioriteringsbudgeten bland annat för att finansiera ett ambitiöst och brett nordiskt samarbetsprogram om integration av flyktingar och invandrare. Det har gjorts en omprioritering $\mathrm{i}$ förhållande till Rysslands- och Vitrysslandssamarbetet under den internationella budgeten för att finansiera insatsen. Dessutom prioritera andra sektorer i Nordiska ministerrådet också samarbete om integrationsfrågan.

Därutöver prioriteras tvärgående insatser om nordiskt statistiksamarbete, miljö och klimat (uppföljning på COP 21), digitalisering samt bekämpning av social marginalisering, extremism och religiös diskriminering genom samarbete om demokrati, inkludering och säkerhet.

Det läggs också stort fokus vid uppföljningen av de strategiska genomlysningarna av det nordiska hälso- och arbetsmarknadssamarbetet, samt den pågående energigenomlysningen i budgeten 2017. Det kommer vidare att sättas i gång en ny strategisk genomlysning i Nordiska ministerrådet under 2017 på miljöområdet. 
Nordiska ministerrådet prioriterar också människors och företags gränsöverskridande aktiviteter i Norden. Gränshinderarbetet ligger fortfarande högt på den politiska agendan, och konsekvenserna av de tillfälliga gränskontrollerna på den fria rörligheten i Norden följs fortlöpande. Det sker också en koordinering och samarbete mellan länderna i nationella lagstiftningsprocesser samt implementering av EU-lagstiftning.

Fokus på internationella frågor och EU-saker har ökat i Nordiska ministerrådet de senaste åren. Det har skett som följd av reformen Nytt Norden. Idag har alla ministerråd internationella och EU-frågor på dagordningen, vilket resulterar i gemensamma deklarationer och aktiviteter riktade mot EU och andra internationella aktörer.

Nordiska ministerrådet har vidare konstaterat att intresset för Norden är ökande runt om i världen. Mot bakgrund av det arbetas det med en gemensam strategi för profilering och positionering av Norden som en attraktiv region både i förhållande till turism, näringsliv och internationellt kapital. Parallellt med detta lanseras under 2017 också ett nytt statsministerinitiativ om nordiska lösningar på globala samhällsutmaningar. Initiativet igångsätts i syfte att öka kunskapen och främja gemensamma nordiska initiativ som kan gå efterfrågan efter innovativa samhällslösningar till mötes inom ramen för områden där de nordiska länderna sitter på stor erfarenhet och kompetens.

Avslutningsvis bör nämnas att Nordiska ministerrådet prioriterar barn- och ungdom, jämställdhet och hållbar utveckling högt och därför integrerar dessa tvärgående perspektiv i hela Nordiska ministerrådets verksamhet. 


\section{Drøftelser med Nordisk Råd om Nordisk Ministerråds budget 2017}

Høsten 2016 ble det gjennomført politiske forhandlinger mellom Nordisk råd og Nordisk ministerråd om ministerrådets budsjettforslag som resulterte i følgende endringer/presiseringer i budsjettet for 2017 :

At avsette 3,413 MDKK til Nordjobb i 2017.

At fortsette å arbeide med den påbegynte analysen som omhandler koordinering og gjensidig informasjonsutveksling når det gjelder autorisasjoner for helsepersonell med det formål å vurdere sikkerhet, samt avsette opp til 0,3 MDKK hvis nåværende finansiering ikke er tilstrekkelig.

At gjenbruk av avfall er et prioritert område i det nordiske samarbeidet. NMR vil i 2017 gjennomføre en analyse og avsette de nødvendige ressurser for å avdekke om nasjonale regelverk, støtteordninger og avgifter på avfallsområdet fremmer eller hemmer måloppnåelse om økt gjenbruk av avfall.

At avsette 1,0 MDKK til å styrke arbeidet med samfunnssikkerhet i Baltikum og Østersjøregionen.

At arbeidet med bioenergi, herunder matavfall, fortsatt blir en viktig komponent i det nordiske samarbeidet. I 2017 gjennomføres en studie som skal undersøke muligheter for videreutvikling av det nordiske samarbeidet innenfor biobrensel og transportsektoren. Studiet skal inkludere eventuelle forslag fra gjennomlysningen av energisektoren som er ferdig mars 2017.

At avsette opp til 1,0 MDKK til å utrede om initiativer angående mobilitet og rettferdig konkurranse på arbeidsmarkedet med særlig fokus på små og mellomstore virksomheter i Baltikum. 
Det var videre et ønske fra Nordisk råd at Nordisk ministerråd skulle slutte med å betale tilbake de ubrukte midlene i Nordisk ministerråd, hvilket er hvorfor følgende henvisning til økonomi-reglementet tilføyes.

I henhold til Økonomireglementet § 20 A skal udisponerte midler som ikke kan overføres til neste budsjettår, tilbakebetales til landene (fra og med 2009) inntil NMR har tilbakebetalt 35 MDKK - deretter settes disse midler på en reservekonto til MR-SAMs disposisjon for det neste budsjettår. Etter regnskapsåret 2015 er det tilbakebetalt 30,2 MDKK. Det forventes at resten av midlerne blir tilbakebetalt av ubrukte midler fra 2016, og at der fra og med 2018 finnes midler på en reservekonto. 


\section{Budgettets indtægter og landenes indbetalinger}

Nordisk Ministerråds budget finansieres i første række af direkte bidrag fra landene. Som udgangspunkt indbetaler landene et beløb svarende til aktivitetsrammen fratrukket afgift på løn, nettorenteindtægter og øvrige indtægter, som det er vist i nedenstående tabel. Landenes indbetalinger sker i henhold til en særskilt fordelingsnøgle, som er beregnet på basis af det respektive lands andel af den samlede bruttonationalindtægt i faktorpriser i Norden for de to seneste kendte år, som i budgettet for 2017 er 2013 og 2014.

\begin{tabular}{|c|c|c|c|c|c|c|c|c|}
\hline $\begin{array}{l}\text { Indtægter } \\
\text { TDKK } \\
\text { (løbende } \\
\text { priser) }\end{array}$ & $\begin{array}{c}\text { Budget } \\
2014\end{array}$ & $\begin{array}{l}\text { Ford. } \\
\text { nøgle } \\
2014\end{array}$ & $\begin{array}{c}\text { Budget } \\
2015\end{array}$ & $\begin{array}{l}\text { Ford. } \\
\text { nøgle } \\
2015\end{array}$ & $\begin{array}{c}\text { Budget } \\
2016\end{array}$ & $\begin{array}{c}\text { Ford. } \\
\text { nøgle } \\
2016\end{array}$ & $\begin{array}{c}\text { Budget } \\
2017\end{array}$ & $\begin{array}{l}\text { Ford. } \\
\text { nøgle } \\
2017\end{array}$ \\
\hline $\begin{array}{l}\text { Afgift } \\
\text { på løn }\end{array}$ & 12.000 & & 13.000 & & 12.500 & & 13.500 & \\
\hline $\begin{array}{l}\text { Øvrige } \\
\text { indtægter } \\
\text { (f.eks. } \\
\text { renter) }\end{array}$ & 1.100 & & 600 & & 400 & & 0 & \\
\hline $\begin{array}{l}\text { Landenes } \\
\text { bidrag }\end{array}$ & 942.115 & & 922.510 & & 914.646 & & 921.591 & \\
\hline - Danmark & 197.844 & $21,0 \%$ & 184.502 & $20,0 \%$ & 177.441 & $19,4 \%$ & 186.161 & $20,2 \%$ \\
\hline - Finland & 153.565 & $16,3 \%$ & 142.989 & $15,5 \%$ & 143.599 & $15,7 \%$ & 145.611 & $15,8 \%$ \\
\hline - Island & 6.595 & $0,7 \%$ & 6.458 & $0,7 \%$ & 7.317 & $0,8 \%$ & 8.294 & $0,9 \%$ \\
\hline - Norge & 288.287 & $30,6 \%$ & 290.591 & $31,5 \%$ & 295.431 & $32,3 \%$ & 292.144 & $31,7 \%$ \\
\hline - Sverige & 295.824 & $31,4 \%$ & 297.971 & $32,3 \%$ & 290.857 & $31,8 \%$ & 289.380 & $31,4 \%$ \\
\hline Sum : & 955.215 & $100 \%$ & 936.110 & $100 \%$ & 927.546 & $100 \%$ & 935.091 & $100 \%$ \\
\hline
\end{tabular}




\section{Landenes prognosticerede indbetalinger i national valuta}

Det er besluttet i Overenskomsten om adgang til videregående uddannelse, at konsekvenserne af betalingsordningen for de nordiske lande skal reguleres over Ministerrådets budget og dermed påvirker landenes bidrag til det nordiske budget. Betalingsordningen gælder Danmark, Finland, Norge og Sverige. Island, Grønland, Færøerne og Åland står uden for betalingsordningen. Der tages hensyn til landenes gensidige betalinger i landenes bidrag, og aftalen påvirker alene den interne fordeling af bidragene mellem landene (Danmark, Finland, Norge og Sverige). Det er i 2015 besluttet, at overenskomsten forlænges til udgangen af 2018.
Af overenskomsten fremgår det, at der skal ske betaling for $75 \%$ af det antal studerende, som modtager studiestøtte fra det land, hvor den studerende er bosat efter gældende regler i det land, og som er indskrevet på en højere uddannelse i et andet land, som falder ind under Artikel 1 i overenskomsten.

Forskningsuddannelser samt studerende på uspecificeret højere uddannelse medregnes ikke i beregningsgrundlaget. Den årlige erstatning pr. studerende er 30.464 DKK i 2017.

Ministerrådet modtager statistik fra de nordiske studiestøttemyndigheder, som ligger til grund for beregningen

\section{Betalingsordning, højere uddannelse TDKK}

Budget 2014 Budget 2015 Budget $2016 \quad$ Budget 2017

$\begin{array}{lrrrr}\text { Danmark } & -89.078 & -85.457 & -83.278 & -78.963 \\ \text { Finland } & 19.777 & 24.387 & 29.137 & 33.861 \\ \text { Island } & 0 & 0 & 0 & 0 \\ \text { Norge } & 58.343 & 59.456 & 57.479 & 51.225 \\ \text { Sverige } & 10.958 & 1.614 & -3.338 & -6.123\end{array}$

Sum:

0

0

0 0 
af det antal studerende mellem de nordiske lande, der indgår i ordningen.

Nedenfor vises landenes indbetalinger til Nordisk Ministerråd i tusinder af det enkelte lands valuta efter

\section{Budget 2017 - Landenes prognosticerede bidrag i national valuta}

$\begin{array}{lrl}\text { Danmark } & 107.199 & \text { DKK } \\ \text { Finland } & 24.090 & \text { EUR } \\ \text { Island } & 153.599 & \text { ISK } \\ \text { Norge } & 429.212 & \text { NOK } \\ \text { Sverige } & 354.070 & \text { SEK }\end{array}$

DKK
EUR
ISK
NOK
SEK

korrektion for betalingsordningen for højere uddannelse og med udgangspunkt i de af samarbejdsministrene godkendte budgetvalutakurser i bilag 2 . 


\section{Udviklingen i Nordisk Ministerråds budget}

En måde at undersøge udviklingen $\mathrm{i}$ Nordisk Ministerrådets budget over langt sigt på er at sammenligne budgettet med de nordiske landes samlede bruttonationalprodukt (BNP). Det nordiske BNP er summen af BNP i Danmark, Finland, Island, Norge og Sverige. Nedenstående graf viser budgettets andel af det nordiske BNP gennem 21 år og det viser, at Ministerrådets budget sammenlignet med BNP falder i perioden.

Sammenligningen er foretaget for perioden 1995-2015, og år 1995 er sat til indeks 100. Forøgelsen af budgettets relative andel i 2009 skyldes primært den økonomiske krise i 2008. Alle landenes BNP faldt i 2009 i forhold til 2008, og som følge heraf udgør Ministerrådets budget det år en større andel af det nordiske BNP.

Det ses af søjlediagrammet, at budgettets andel af BNP udgjorde indeks 56 i 2015 . Hvis gennemsnittet af to femårsperioder sammenlignes, dvs. på den ene side årene 1995-1999 og på den anden side 2011-2015, udgør faldet en tredjedel.

\section{NMR-budget som andel af BNP-norden}

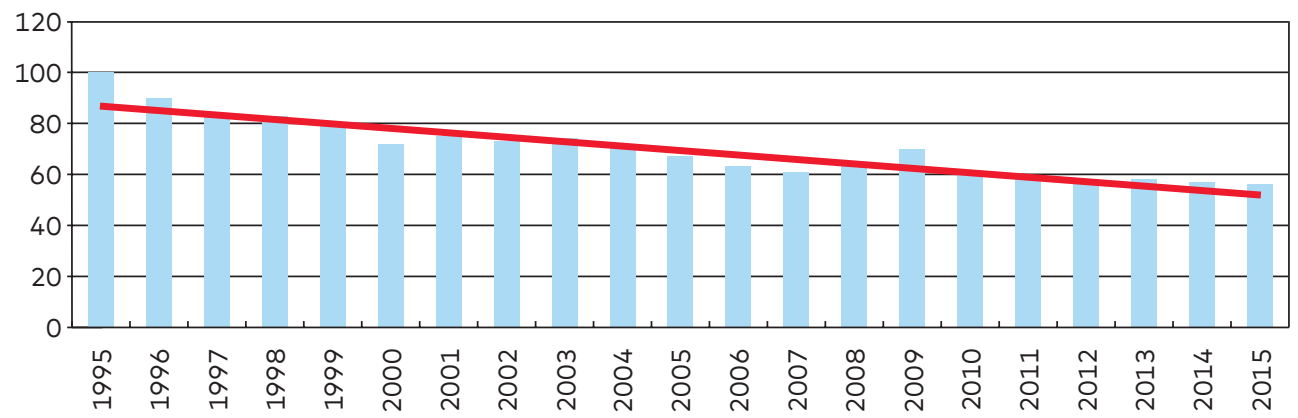




\section{Budgettets udvikling i perioden 2005-2017}

Budgettets udvikling i perioden 2005-2017

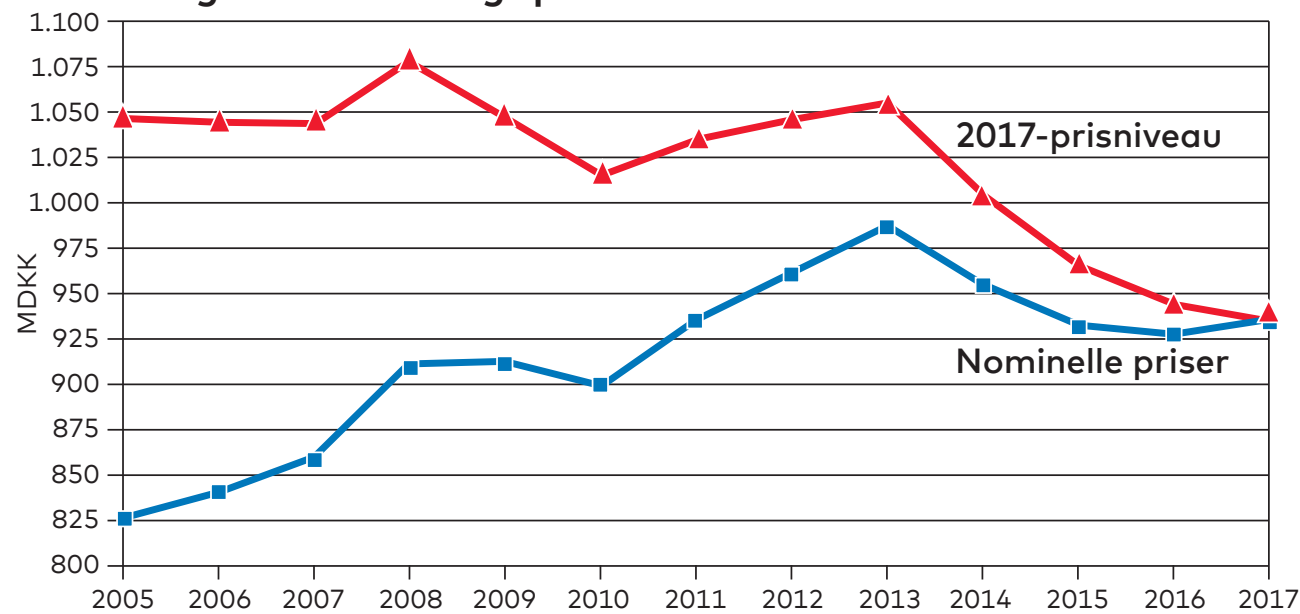

MR-SAM har for 2017 vedtaget en ramme, der er på niveau med budget 2016.

Niveauskiftet i 2008 skal ses på baggrund af beslutningen i forbindelse med budget 2008 om at finansiere en del af globaliseringssatsninger på 60 MDKK i 2008, som statsministrene lancerede i Punkaharju i Finland i juni 2007, med en forøgelse af aktivitetsrammen på $35 \mathrm{MDKK}$.

Når budgettet i faste priser i 2010 falder i forhold til 2009, og fortsat i 2011 ligger under niveauet for 2009, skyldes det de udsving, der har været i valutakurserne. I dette tilfælde skyldes det konkret det store fald i norske og svenske kroners værdi fra sidste halvdel af 2008 til midten af 2009 i forhold til danske kroner. Stigningen fra 2011 til 2012 og forsat til 2013 skyldes på samme måde stigningen i norske og svenske kroner i forhold til danske kroner. Det relativt store fald i faste priser i 2015 og fortsat i 2016 skyldes - foruden de nedskæringer, der har været i budgettet - faldet i norske og svenske kroners værdi i forhold til danske kroner. 


\section{Besparelse i det nordiske budget 2014-2016}

Budgetrammen for Nordisk Ministerråds budget er sammenlagt beskåret med 8 \% i faste priser i årene
2014-2016. Nedenstående tabel viser fordelingen af besparelserne på sektorer*:

\section{Fordeling af besparelserne på sektorer*:}

\begin{tabular}{|c|c|c|c|c|c|c|}
\hline Besparelser i TDKK & $\begin{array}{l}2014 \text { i } \\
\text { henhold } \\
\text { til bud- } \\
\text { get } 2013\end{array}$ & $\begin{array}{c}\% \text { af } \\
\text { sekt. } \\
\text { størrelse }\end{array}$ & $\begin{array}{l}2015 \text { i } \\
\text { henhold } \\
\text { til bud- } \\
\text { get } 2014\end{array}$ & $\begin{array}{c}\% \text { af } \\
\text { sekt. } \\
\text { størrelse }\end{array}$ & $\begin{array}{l}2016 \text { i } \\
\text { henhold } \\
\text { til bud- } \\
\text { get } 2015\end{array}$ & $\begin{array}{c}\% \text { af } \\
\text { sekt. } \\
\text { størrelse }\end{array}$ \\
\hline Samarbejdsministrene & -20.734 & $-7 \%$ & -5.138 & $-2 \%$ & -6.523 & $-3 \%$ \\
\hline Uddannelse og forskning & -9.201 & $-4 \%$ & -4.768 & $-2 \%$ & -2.795 & $-1 \%$ \\
\hline Social- og Helsepolitik & -1.772 & $-4 \%$ & -806 & $-2 \%$ & 0 & $0 \%$ \\
\hline Kulturpolitik & -8.203 & $-5 \%$ & -3.358 & $-2 \%$ & 0 & $0 \%$ \\
\hline $\begin{array}{l}\text { Fiskeri og havbrug, } \\
\text { Jordbrug, Levneds- } \\
\text { midler og Skovbrug }\end{array}$ & -1.715 & $-4 \%$ & -822 & $-2 \%$ & 0 & $0 \%$ \\
\hline Ligestilling & -339 & $-4 \%$ & -178 & $-2 \%$ & 0 & $0 \%$ \\
\hline $\begin{array}{l}\text { Närings-, Energi- og } \\
\text { Regionalpolitik }\end{array}$ & -5.026 & $-4 \%$ & -2.809 & $-2 \%$ & 0 & $0 \%$ \\
\hline Miljø & -1.696 & $-4 \%$ & -888 & $-2 \%$ & 0 & $0 \%$ \\
\hline Arbejdsmarkedspolitik & -535 & $-4 \%$ & -274 & $-2 \%$ & 0 & $0 \%$ \\
\hline Ekonomi og Finanspolitik & -65 & $-4 \%$ & -36 & $-2 \%$ & 0 & $0 \%$ \\
\hline Lagstiftning & -50 & $-4 \%$ & -28 & $-2 \%$ & 0 & $0 \%$ \\
\hline & -49.336 & $-5 \%$ & -19.105 & $-2 \%$ & -9.318 & $-1 \%$ \\
\hline
\end{tabular}

*Besparelser pr. budgetår er sammenlignet med budgettet året inden i dets års prisniveau. 


\section{Udviklingen i udisponerede midler 2012-2015}

Udisponerede midler er defineret som midler, hvor der ikke er foretaget en beslutning om anvendelse til et bestemt formål. Udisponerede midler kan alene forekomme under budgetposter med projektmidler og programlignende aktiviteter, idet Ministerrådet på institutioner og organisationsbidrag udbetaler alle midler til eksterne parter, som har dispositionsretten over midlerne, og derfor er disse midler i Ministerrådets budget altid pr. definition $100 \%$ disponeret. Projektmidler og programlignende aktiviteter udgjorde totalt ca. $56 \%$ af Ministerrådets budget i 2015.

I forbindelse med en tidligere modernisering af budgettet og vedtagelse af Generalsekretærens forslagskatalog i 2007 besluttede MR-SAM at indføre en $20 \%$-regel kombineret med et minimumsbeløb på 200.000 DKK, som betød, at højst $20 \%$ af årets budget på en budgetpost kunne videreføres til næste år; dog kunne man altid videreføre 200.000 DKK. Denne regel er med moderniseringen af budgettet i 2014 ændret til en $15 \%$-regel med et minimumsbeløb på 150.000 DKK.

Samarbejdsministrene besluttede i maj måned 2009, at fra og med virksomhedsår 2009 skal midler, som falder for $15 \%$-reglen, tilbageføres til landene. Beslutningen er taget på baggrund af, at budgetrammen i 2008 blev udvidet med et engangsløft på 35 MDKK til finansiering af globaliseringsinitiativerne.

Herunder vises en grafisk fremstilling af de udisponerede midler i 2012-2015 samt en oversigt over fordelingen af de udisponerede midler fordelt på ministerråd i TDKK og i procent af sektorens samlede ramme.

Den ufrivillige opbremsning af aktiviteter i Rusland i 2015 på grund af Nordisk Ministerråds

1 Minimumsgrænsen er indført af hensyn til de små projektbudgetposter, som en procentordning alene vil ramme uforholdsmæssigt hårdt. 


\section{Udisponerede midler ultimo 2012-2015}

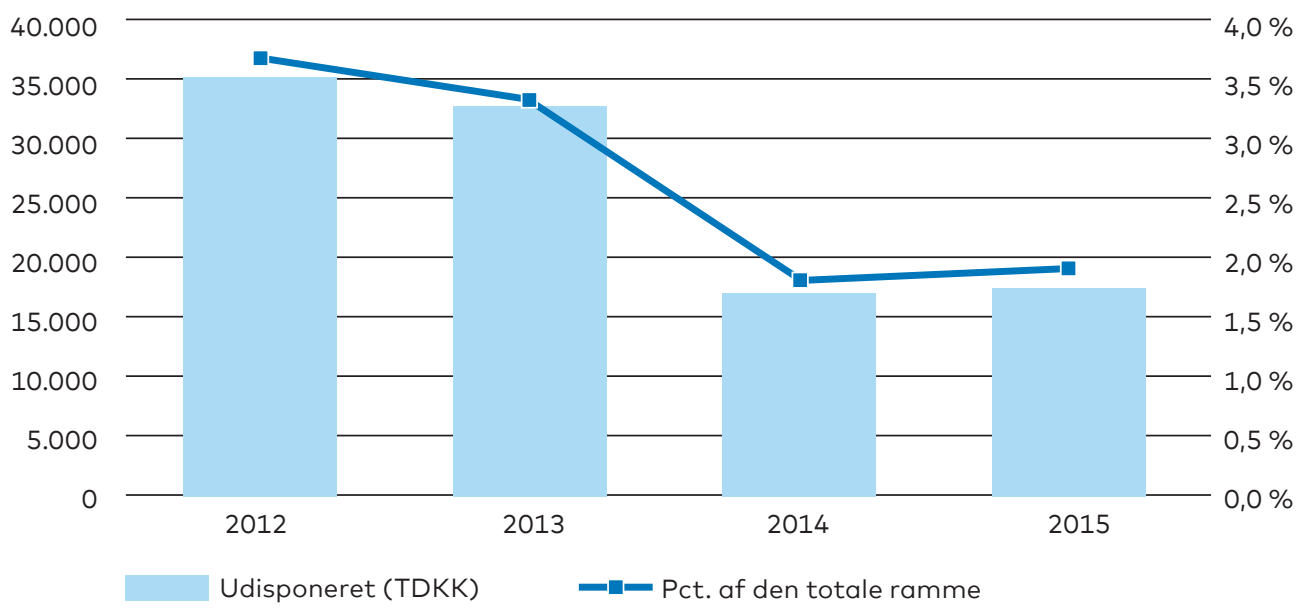

klassificering som udenlandsk agent resulterede $i$, at en stor del af Ruslandsmidlerne blev tilbagebetalt. Af disse midler er ca. 5 MDKK beskåret jf. 15 \%-reglen. Dette forklarer den største del af totalbeløbet for de beskårne midler, se tabellen nedenfor. Desuden er ca.
5 MDKK af de tilbagebetalte midler overført til 2016 som udisponerede midler. Hvis Ruslandsmidlerne ikke skulle inkluderes i regnskabet, ville de udisponerde midler, der overføres til 2016, udgøre 13,1 MDKK, svarende til $1,4 \%$ af det samlede budget. 


\section{Udisponerede midler ultimo 2012-2015}

\begin{tabular}{|c|c|c|c|c|c|c|c|c|c|}
\hline Sektor (TDKK) & 2012 & $\begin{array}{l}\% \text { af } \\
\text { sekt. } \\
\text { stør- } \\
\text { relse }\end{array}$ & 2013 & $\begin{array}{l}\% \text { af } \\
\text { sekt. } \\
\text { stør- } \\
\text { relse }\end{array}$ & 2014 & $\begin{array}{l}\% \text { af } \\
\text { sekt. } \\
\text { stør- } \\
\text { relse }\end{array}$ & 2015 & $\begin{array}{l}\% \text { af } \\
\text { sekt. } \\
\text { stør- } \\
\text { relse }\end{array}$ & $\begin{array}{c}\text { Beskå- } \\
\text { ret jf. } \\
15 \% \\
\text { regl. }\end{array}$ \\
\hline $\begin{array}{l}\text { Prioriterings- } \\
\text { budgettet }\end{array}$ & - & & 3.242 & $4 \%$ & 3.939 & $5 \%$ & 3.841 & $5 \%$ & 766 \\
\hline $\begin{array}{l}\text { Internationalt } \\
\text { samarbejde }\end{array}$ & 6.969 & $7 \%$ & 8.474 & $9 \%$ & 2.618 & $3 \%$ & 6.090 & $8 \%$ & 4.872 \\
\hline $\begin{array}{l}\text { Uddannelse og } \\
\text { forskning }\end{array}$ & 10.612 & $5 \%$ & 11.064 & $5 \%$ & 1.970 & $1 \%$ & 1.049 & $0 \%$ & 342 \\
\hline $\begin{array}{l}\text { Social- og } \\
\text { Helsepolitik }\end{array}$ & 361 & $1 \%$ & 897 & $2 \%$ & 865 & $2 \%$ & 268 & $1 \%$ & 0 \\
\hline MR-FJLS & 623 & $2 \%$ & 856 & $2 \%$ & 1.714 & $4 \%$ & 122 & $0 \%$ & 0 \\
\hline Kulturpolitik & 1.548 & $1 \%$ & 788 & $0 \%$ & 593 & $0 \%$ & 1.473 & $1 \%$ & 0 \\
\hline Ligestilling & 465 & $5 \%$ & 1.045 & $11 \%$ & 28 & $0 \%$ & 142 & $2 \%$ & 0 \\
\hline MR-NER & 1.450 & $1 \%$ & 781 & $1 \%$ & 2.347 & $2 \%$ & 1.541 & $1 \%$ & 0 \\
\hline Miljø & 672 & $2 \%$ & 716 & $2 \%$ & 629 & $1 \%$ & 1.111 & $3 \%$ & 0 \\
\hline Arbejdslivspolitik & 1.028 & $8 \%$ & 1.103 & $8 \%$ & 883 & $6 \%$ & 396 & $3 \%$ & 0 \\
\hline $\begin{array}{l}\text { Ekonomi og } \\
\text { Finanspolitik }\end{array}$ & 165 & $9 \%$ & 54 & $3 \%$ & 67 & $4 \%$ & 191 & $11 \%$ & 0 \\
\hline Lagstiftning & 223 & $16 \%$ & 188 & $13 \%$ & 209 & $15 \%$ & 207 & $15 \%$ & 28 \\
\hline$\varnothing$ vrig virksomhet & 11.128 & $6 \%$ & 3.564 & $3 \%$ & 1.342 & $1 \%$ & 1.190 & $1 \%$ & 591 \\
\hline SUM & 35.244 & $3,7 \%$ & 32.772 & $3,3 \%$ & 17.204 & $1,8 \%$ & 17.623 & $1,9 \%$ & 6.599 \\
\hline
\end{tabular}




\section{Likviditetens udvikling}

Likviditetens udvikling

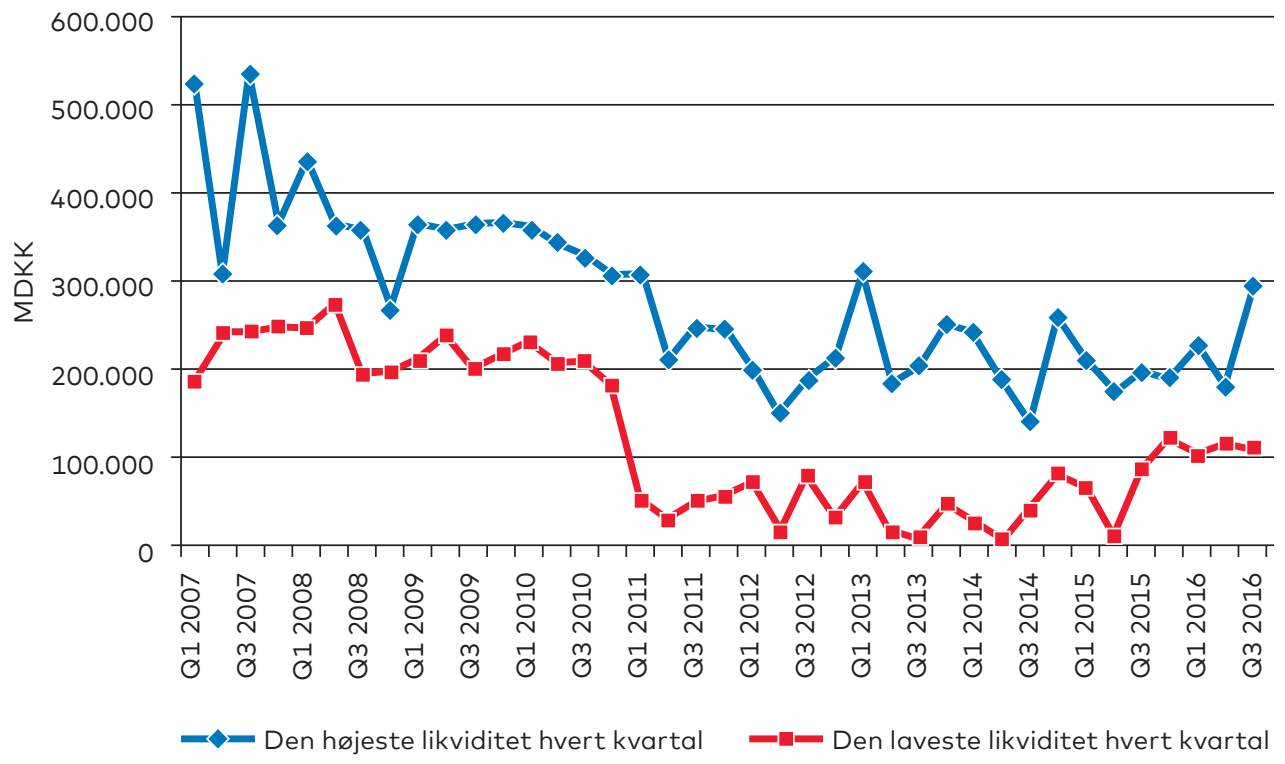

Denne graf viser to serier. Den ene viser den samlede likviditets højeste punkt hvert kvartal og den anden den laveste. Likviditetsbeholdningen indeholder Ministerrådets totale likviditet, hvor likviditeten i anden valuta end dansk er omregnet til danske kroner.

Fra og med budgetåret 2008 er landene begyndt at indbetale 4 gange årligt mod tidligere 2 gange, hvilket indebærer et ændret mønster i
Ministerrådets likviditetsbeholdning. Fra og med midten af året 2014 er landene begyndt at indbetale 8 gange om året, hvor 4 indbetalinger er $\mathrm{i}$ DKK og 4 er i landenes valuta.

MR-SAM besluttede i november 2010 at forskyde landenes indbetalinger med to måneder. Effekten heraf er, at Ministerrådets samlede likviditet er reduceret betydeligt allerede i 2011 og på visse tidspunkter derefter er tæt på nul. 


\section{Oversigt over Nordisk Ministerråds budget på budgetpostniveau}

\begin{tabular}{|c|c|c|c|}
\hline \multirow[t]{2}{*}{ TDKK } & & $\begin{array}{l}\text { Budget } \\
2017\end{array}$ & $\begin{array}{l}\text { Budget } \\
2016\end{array}$ \\
\hline & Sum Prioriteringsbudgettet (MR-SAM) & 91.842 & 75.641 \\
\hline & Formandskapspuljen, Norge & 15.270 & 0 \\
\hline $1-8019$ & $\begin{array}{l}\text { Grønn omstilling og konkurransekraft } \\
\text { i nordiske byregioner }\end{array}$ & 2.749 & 0 \\
\hline $1-8020$ & Blå og grønn bioøkonomi & 3.563 & 0 \\
\hline $1-8021$ & Helse & 2.341 & 0 \\
\hline $1-8022$ & Integration & 5.294 & 0 \\
\hline $1-8023$ & $\begin{array}{l}\text { Styrket samarbeid mellom de utenrikspolitiske } \\
\text { instituttene }\end{array}$ & 509 & 0 \\
\hline \multirow[t]{2}{*}{$1-8024$} & Nordisk energisamarbeid & 814 & 0 \\
\hline & Formandskapspuljen, Finland & 15.273 & 15.256 \\
\hline $1-8012$ & $\begin{array}{l}\text { Statistisk utredning över nordisk rörlighet och } \\
\text { förmåner över gränserna }\end{array}$ & 3.818 & 3.814 \\
\hline $1-8013$ & $\begin{array}{l}\text { Forskarutbyte mellan de nordiska utrikespolitiska } \\
\text { instituten }\end{array}$ & 764 & 763 \\
\hline $1-8014$ & $\begin{array}{l}\text { Miljömärkning Svanen, cirkulär ekonomi och } \\
\text { miljöavtryck }\end{array}$ & 764 & 763 \\
\hline $1-8015$ & $\begin{array}{l}\text { Ett innovativt och öppet Norden med välmående } \\
\text { människor } 2020\end{array}$ & 2.291 & 2.288 \\
\hline $1-8016$ & Nordisk vägkarta för Blå Bioekonomi & 2.291 & 2.288 \\
\hline $1-8017$ & Socio-ekonomisk nytta av arktiska ytvatten i Norden & 1.527 & 1.526 \\
\hline \multirow[t]{2}{*}{$1-8018$} & The Rising North & 3.818 & 3.814 \\
\hline & Formandskapspuljen, Danmark & 14.643 & 15.256 \\
\hline $1-8008$ & Vækst & 3.954 & 4.068 \\
\hline $1-8009$ & Velfærd & 4.072 & 4.068 \\
\hline $1-8010$ & Værdier & 4.072 & 4.577 \\
\hline \multirow[t]{2}{*}{ 1-8011 } & Det blå Arktis & 2.545 & 2.543 \\
\hline & Formandskapspuljen, Island & 0 & 15.255 \\
\hline $1-8005$ & Den nordiska spellistan & 0 & 2.034 \\
\hline $1-8006$ & Välfärdsvakten & 0 & 3.051 \\
\hline $1-8007$ & Bioekonomi-initativet & 0 & 10.170 \\
\hline
\end{tabular}




\begin{tabular}{|c|c|c|c|}
\hline & Prioriteringspuljen & 46.656 & 29.874 \\
\hline $1-8410$ & Politiska prioriteringar & 7.126 & 6.102 \\
\hline $1-8411$ & Politiske initiativer i nærområderne & 8.593 & 3.432 \\
\hline $1-8412$ & Till disposition för MR-SAM & 5.283 & 0 \\
\hline $1-8420$ & Profilering og positionering & 10.180 & 10.170 \\
\hline $1-8510$ & Nye tværgående initiativer & 5.294 & 10.170 \\
\hline $1-8520$ & Nordiska lösningar på globala samhällsutmaningar & 10.180 & 0 \\
\hline
\end{tabular}

\begin{tabular}{|c|c|c|c|}
\hline \multirow[t]{2}{*}{ TDKK } & & $\begin{array}{c}\text { Budget } \\
2017\end{array}$ & $\begin{array}{c}\text { Budget } \\
2016\end{array}$ \\
\hline & Sum Fællesaktiviteter og Sekretariatet (MR-SAM) & 111.081 & 109.424 \\
\hline & Nordisk Ministerråds fællesaktiviteter & 31.837 & 31.274 \\
\hline $1-0410$ & Föreningarna Nordens Förbund & 3.341 & 3.282 \\
\hline $1-0425$ & Bidrag til Grönland & 750 & 737 \\
\hline $1-0435$ & Generalsekreterarens disponeringsreserv & 427 & 419 \\
\hline $1-0460$ & Hållbar utveckling (tidigare Hållbart Norden) & 3.132 & 3.077 \\
\hline $1-1011$ & Informationsaktiviteter & 5.345 & 5.250 \\
\hline $1-1012$ & Norden i Fokus & 4.766 & 4.362 \\
\hline $1-1030$ & Hallo Norden & 6.596 & 6.799 \\
\hline $1-1036$ & Grænsehindringer i Norden & 5.061 & 4.972 \\
\hline $1-1050$ & Tjänstemannautbyte & 1.194 & 1.173 \\
\hline \multirow[t]{2}{*}{$1-2534$} & Bidrag til Nordisk sommaruniversitet (NSU) & 1.225 & 1.203 \\
\hline & Ministerrådets sekretariat (NMRS) & 79.244 & 78.150 \\
\hline $1-0180$ & Ministerrådets sekretariat (NMRS) & 79.244 & 78.150 \\
\hline
\end{tabular}

\begin{tabular}{|c|c|c|c|}
\hline TDKK & & $\begin{array}{l}\text { Budget } \\
2017\end{array}$ & $\begin{array}{l}\text { Budget } \\
2016\end{array}$ \\
\hline & Sum Internationalt samarbejde (MR-SAM) & 55.261 & 68.919 \\
\hline $1-0820$ & Kunskapsuppbyggning och nätverk & 17.876 & 27.560 \\
\hline $1-0980$ & Partnerskab og grænseregionalt samarbejde & 2.562 & 2.517 \\
\hline $1-0960$ & NGO-virksomhed i Østersøregionen & 6.548 & 6.432 \\
\hline $1-0810$ & $\begin{array}{l}\text { Ministerrådets kontorer i Estland, Letland, Litauen } \\
\text { og Nordvestrusland }\end{array}$ & 15.778 & 15.560 \\
\hline $1-0850$ & Internationellt samarbete & 1.815 & 1.783 \\
\hline $1-0870$ & Arktisk samarbeidsprogram & 9.024 & 8.864 \\
\hline $1-0950$ & Hvideruslandsaktiviteter & 0 & 4.574 \\
\hline $1-0990$ & Samarbejde med Nordens naboer i Vest & 1.658 & 1.629 \\
\hline
\end{tabular}


TDKK

Budget Budget

2017

2016

Sum Uddannelse og forskning (MR-U)

$221.541 \quad 222.919$

Generelle utdannings- og forskningsinnsatser

$3.376 \quad 3.316$

2-2505 Dispositionsmedel Utbildning och forskning

3.376

3.316

Politikudvikling m.v.

$15.718 \quad 15.440$

2-2544 Det nordiske sprogsamarbejde

$7.123 \quad 6.997$

2-2553 Politikudvikling, Videnssamfund og IT-infrastruktur

576

566

2-3127 Politikudvikling voksnes læring

$8.019 \quad 7.877$

Mobilitets- og netværksprogrammer

$80.306 \quad 77.713$

2-2513 Nordplus

$74.809 \quad 74.073$

2-2515 Nordic Master Programme

5.497

3.640

Institution

$99.442 \quad 104.153$

2-3100 NordForsk

$99.442 \quad 104.153$

Forskning i øvrigt

$22.699 \quad 22.297$

2-3180 Nordisk Institut for Teoretisk Fysik (NORDITA)

$9.320 \quad 9.155$

2-3181 Nordiska Institutet for Sjörett (NIfS)

$2.778 \quad 2.729$

2-3182 Nordisk Institutt for Asiastudier (NIAS)

$4.403 \quad 4.325$

2-3184 Nordisk vulkanologisk institut (NORDVULK)

$4.498 \quad 4.418$

2-3185 Nordisk Samisk Institutt (NSI)

$1.700 \quad 1.670$

TDKK

Budget Budget 2017 2016

Sum Social- og Helsepolitik (MR-S)

$39.363 \quad 38.732$

Projektmedel

$19.280 \quad 18.938$

3-4310 Projekmedel - Social- och hälsovårdspolitik

$5.748 \quad 4.646$

3-4311 Nordisk helsesamarbejde - opfølgning af

$1.287 \quad 1.264$

Bo Könbergs rapport

3-4320 Rådet för nordiskt samarbete om funktionshinder

$1.163 \quad 1.142$

3-4340 Nomesko og Nososko

$1.959 \quad 1.924$

3-4382 NIOM AS - Nordisk institutt for Odontologiske

$9.123 \quad 9.962$ Materialer

Institutioner

$20.083 \quad 19.794$

3-4380 Nordens Välfärdcenter (NVC)

$20.083 \quad 19.794$




\begin{tabular}{|c|c|c|c|}
\hline \multirow[t]{2}{*}{ TDKK } & \multirow[b]{2}{*}{ Sum Kulturpolitik (MR-K) } & \multirow{2}{*}{$\begin{array}{c}\text { Budget } \\
2017 \\
174.413\end{array}$} & \multirow{2}{*}{$\begin{array}{c}\text { Budget } \\
2016 \\
170.551\end{array}$} \\
\hline & & & \\
\hline & Generelle kulturinnsatser & 51.496 & 51.085 \\
\hline 4-2203 & Dispositionsmidler Kultur & 974 & 957 \\
\hline 4-2205 & Nordisk kulturfond & 35.555 & 34.926 \\
\hline 4-2206 & Nordisk Råds priser & 4.281 & 3.905 \\
\hline $4-2208$ & Strategiska satsningar & 10.686 & 11.297 \\
\hline \multirow[b]{2}{*}{$4-2212$} & Barn och unga & 6.250 & 6.139 \\
\hline & Nordisk Børne- og Ungdomskomité (NORDBUK) & 6.250 & 6.139 \\
\hline & Film och media & 31.846 & 31.283 \\
\hline 4-2222 & Nordisk Film- och TV-fond & 28.849 & 28.339 \\
\hline \multirow[t]{2}{*}{$4-2228$} & NORDICOM & 2.997 & 2.944 \\
\hline & Konstområdet & 31.820 & 31.258 \\
\hline 4-2251 & Kultur-og kunstprogrammet & 16.813 & 16.516 \\
\hline $4-2253$ & Nordisk oversættelsesstøtte & 3.175 & 3.119 \\
\hline \multirow[t]{2}{*}{ 4-2254 } & Nordiskt-baltiskt mobilitetsprogram för Kultur & 11.832 & 11.623 \\
\hline & Nordiska kulturhus (institutioner) & 46.010 & 44.219 \\
\hline 4-2270 & Nordens hus i Reykjavik (NOREY) & 11.148 & 9.880 \\
\hline 4-2272 & Nordens hus på Färöarna (NLH) & 13.884 & 13.692 \\
\hline $4-2274$ & Nordens institut på Åland (NIPÅ) & 3.023 & 2.973 \\
\hline 4-2277 & Nordens institut på Grönland (NAPA) & 6.507 & 6.417 \\
\hline \multirow[t]{2}{*}{ 4-2548 } & Kulturkontakt Nord (KKN) & 11.448 & 11.257 \\
\hline & Andra kultursatsningar & 6.991 & 6.567 \\
\hline 4-2232 & Prioriterede verksamheter & 3.100 & 2.745 \\
\hline 4-2234 & Samisk samarbeid & 3.891 & 3.822 \\
\hline
\end{tabular}

\begin{tabular}{|c|c|c|c|}
\hline TDKK & & $\begin{array}{c}\text { Budget } \\
2017\end{array}$ & $\begin{array}{c}\text { Budget } \\
2016\end{array}$ \\
\hline & Sum Jämställhet (MR-JÄM) & 9.185 & 9.023 \\
\hline & Projektmedel & 9.185 & 9.023 \\
\hline $6-4410$ & Projektmedel - Jämställdhet & 3.616 & 3.552 \\
\hline $6-4420$ & MR-JÄMs stödordning & 2.942 & 2.890 \\
\hline $6-4480$ & Nordisk information för kunskap om kön (NIKK) & 2.627 & 2.581 \\
\hline
\end{tabular}


TDKK

Budget Budget $2017 \quad 2016$

Sum Fiskeri og havbrug, Levnedsmidler og Skovbrug (MR-FJLS)

$40.219 \quad 39.572$

5-6420 Ny nordisk mad $939 \quad 922$

Fiskeri

$6.416 \quad 6.303$

5-6610 Projektmedel - Fiskeri

$6.416 \quad 6.303$

Jord-och skovbrug

$27.074 \quad 26.659$

5-6510 Projektmidler Jordbrug

382

375

5-6520 Nordiskt kontaktorgan för jordbruksforskning (NKJ)

848 833

5-6310 Projektmidler Skovbrug 311

5-6581 Samnordisk skogsforskning (SNS)

317

5.656

Institutioner - jordbrug

5.758

19.484

5-6585 Nordisk Genressource Center (NordGen)

19.769

19.484

Levnedsmidler

19.769

$\begin{array}{ll}5.790 & 5.688 \\ 5.224 & 5.132\end{array}$

5-6810 Projektmedel - Levnedsmidler

5-6830 Nordisk handlingsplan for bedre helse og livskvalitet

566

556

TDKK

Budget Budget

2017

2016

\begin{tabular}{|c|c|c|c|}
\hline & $\begin{array}{l}\text { Sum Näring-, Energi- och Regionalpolitik } \\
\text { (MR-NER) }\end{array}$ & 129.080 & 130.773 \\
\hline & Näring & 85.664 & 87.766 \\
\hline $7-5140$ & Projektmidler Näring & 2.056 & 2.020 \\
\hline \multirow[t]{2}{*}{$7-5280$} & Nopef & 15.698 & 15.420 \\
\hline & Institutioner - Näring & 67.910 & 70.326 \\
\hline \multirow[t]{2}{*}{$7-5180$} & Nordisk Innovation (NI) & 67.910 & 70.326 \\
\hline & Energi & 10.322 & 10.461 \\
\hline \multirow[t]{2}{*}{ 7-5141 } & Projektmidler Energi & 4.276 & 4.200 \\
\hline & Institutioner - Energi & 6.046 & 6.261 \\
\hline \multirow[t]{2}{*}{$7-3220$} & Nordisk Energiforskning (NEF) & 6.046 & 6.261 \\
\hline & Regional & 33.094 & 32.546 \\
\hline 7-5143 & $\begin{array}{l}\text { Impl. af samarbetsprogram, demografi, } \\
\text { arbetsgrupper och projekmedel - Regional }\end{array}$ & 5.507 & 5.410 \\
\hline 7-5151 & NORA & 6.858 & 6.737 \\
\hline \multirow[t]{2}{*}{ 7-5160 } & Grenseregionalt samarbeid & 9.615 & 9.445 \\
\hline & Institutioner - Regional & 11.114 & 10.954 \\
\hline $7-6180$ & Nordregio & 11.114 & 10.954 \\
\hline
\end{tabular}




\begin{tabular}{llrr} 
& & $\begin{array}{c}\text { Budget } \\
\text { TDKK }\end{array}$ & \multicolumn{1}{c}{$\begin{array}{c}\text { Budget } \\
2017\end{array}$} \\
& Sum Miljø (MR-Miljø) & $\mathbf{4 5 . 7 1 6}$ & $\mathbf{4 4 . 9 0 7}$ \\
\hline 8-3310 & Dispositionsmidler Miljø & 4.686 & 4.313 \\
$8-3311$ & Miljøsektorens arbejdsgrupper & 24.443 & 24.511 \\
8-3312 & Nordisk Råds miljøpris & 835 & 610 \\
8-3320 & NEFCOS Miljøudviklingsfond & 11.405 & 11.203 \\
8-6720 & SVANEN - Nordisk miljömärkning & 4.347 & 4.270 \\
& & &
\end{tabular}

\begin{tabular}{|c|c|c|c|}
\hline \multirow[t]{2}{*}{ TDKK } & & $\begin{array}{c}\text { Budget } \\
2017\end{array}$ & $\begin{array}{c}\text { Budget } \\
2016\end{array}$ \\
\hline & Sum Arbetslivspolitik (MR-A) & 14.086 & 13.839 \\
\hline & Projektmedel & 10.625 & 10.436 \\
\hline $9-4110$ & Projektmidler i øvrigt - Arbejdsliv & 1.064 & 922 \\
\hline 9-4111 & Arbejdsliv faste udvalg & 4.620 & 4.661 \\
\hline $9-4120$ & Nordjobb & 3.272 & 3.214 \\
\hline $9-4130$ & Kommunikation om arbejdsliv & 1.669 & 1.639 \\
\hline & Institutioner & 3.461 & 3.403 \\
\hline $9-4180$ & $\begin{array}{l}\text { Nordiska Institutionen för Vidareutbildning inom } \\
\text { Arbetsmiljöområdet (NIVA) }\end{array}$ & 3.461 & 3.403 \\
\hline
\end{tabular}

\begin{tabular}{|c|c|c|c|}
\hline \multirow[t]{2}{*}{ TDKK } & & $\begin{array}{c}\text { Budget } \\
2017\end{array}$ & $\begin{array}{c}\text { Budget } \\
2016\end{array}$ \\
\hline & Sum Ekonomi- og Finanspolitik (MR-Finans) & 1.874 & 1.841 \\
\hline $10-5210$ & Projektmedel- Ekonomi och finanspolitik & 1.874 & 1.841 \\
\hline
\end{tabular}

\begin{tabular}{|c|c|c|c|}
\hline \multirow[t]{2}{*}{ TDKK } & & $\begin{array}{c}\text { Budget } \\
2017\end{array}$ & $\begin{array}{c}\text { Budget } \\
2016\end{array}$ \\
\hline & Sum Lagstifning (EK-LÄG) & 1.430 & 1.405 \\
\hline $11-7110$ & Projektmedel - Lagstiftning & 1.430 & 1.405 \\
\hline
\end{tabular}




\section{Bilag 1}

\begin{tabular}{|c|c|c|c|c|}
\hline \multicolumn{2}{|c|}{ De nordiske institutioners bevillinger } & 2017 & 2016 & \multirow[b]{3}{*}{ NOK } \\
\hline MR-U & & & & \\
\hline $2-3100$ & NordForsk & 124.303 .000 & 122.533 .000 & \\
\hline \multicolumn{5}{|l|}{ MR-S } \\
\hline $3-4380$ & Nordens Välfärdscenter (NVC) & 25.104 .000 & 24.743 .000 & SEK \\
\hline \multicolumn{5}{|l|}{ MR-K } \\
\hline $4-2270$ & Nordens hus i Reykjavik (NOREY) & 206.438 .000 & 197.597.000 & IKR \\
\hline $4-2272$ & Nordens hus på Färöarna (NLH) & 13.884 .000 & 13.692 .000 & DKK \\
\hline $4-2274$ & Nordens institut på Åland (NIPÅ) & 405.800 & 399.000 & EUR \\
\hline 4-2277 & $\begin{array}{l}\text { Nordens institut på Grönland } \\
\text { (NAPA) }\end{array}$ & 6.507 .000 & 6.417 .000 & DKK \\
\hline $4-2548$ & Kulturkontakt Nord (KKN) & 1.536 .700 & 1.511 .000 & EUR \\
\hline \multicolumn{5}{|c|}{ MR-FJLS } \\
\hline $5-6585$ & $\begin{array}{l}\text { Nordisk Genressource Center } \\
\text { (NordGen) }\end{array}$ & 24.711 .000 & 24.355 .000 & SEK \\
\hline \multicolumn{5}{|l|}{ MR-NER } \\
\hline $7-5180$ & Nordisk Innovation (NI) & 84.888 .000 & 82.737 .000 & NOK \\
\hline $7-3220$ & Nordisk Energiforskning (NEF) & 7.558 .000 & 7.366 .000 & NOK \\
\hline $7-6180$ & Nordregio & 13.893 .000 & 13.693 .000 & SEK \\
\hline \multicolumn{5}{|l|}{ MR-A } \\
\hline $9-4180$ & $\begin{array}{l}\text { Institut för vidareutb.inom arbets- } \\
\text { miljö (NIVA) }\end{array}$ & 464.600 & 456.800 & EUR \\
\hline
\end{tabular}




\section{Bilag 2}

\section{Valutakurser og inflations-}

satser 2017

$\begin{array}{ll}100 \mathrm{EUR} & =745 \mathrm{DKK} \\ 100 \mathrm{ISK} & =5,4 \mathrm{DKK} \\ 100 \mathrm{NOK}= & 80 \mathrm{DKK} \\ 100 \mathrm{SEK} & =80 \mathrm{DKK} \\ \text { Danmark } & 1,4 \% \\ \text { Finland } & 1,1 \% \\ \text { Island } & 2,4 \% \\ \text { Norge } & 2,6 \% \\ \text { Sverige } & 1,46 \%\end{array}$

Omregningsfaktoren for projektmidler er 1,8\% 
<smiles>O</smiles>

Nordisk Ministerråd

Ved Stranden 18

1061 København K

www.norden.org

\section{ANP 2017:706}

ISBN 978-92-893-4857-7 (PRINT)

ISBN 978-92-893-4858-4 (PDF) 